\title{
Pap smear in antepartum women: an opportunity to screen and create awareness
}

\author{
Shanthi Ethirajan*, Srinidhi R., Jayashree K., \\ Department of Obstetrics and Gynecology, Saveetha Medical College, Thandalam, Tamil Nadu, India
}

Received: 28 July 2018

Accepted: 27 August 2018

\section{*Correspondence:}

Dr. Shanthi Ethirajan,

E-mail: dreshanthi@gmail.com

Copyright: $\odot$ the author(s), publisher and licensee Medip Academy. This is an open-access article distributed under the terms of the Creative Commons Attribution Non-Commercial License, which permits unrestricted non-commercial use, distribution, and reproduction in any medium, provided the original work is properly cited.

\begin{abstract}
Background: Cervical and breast cancers are the leading malignancies in females in India. Cancer cervix is preventable and treatable if detected at premalignant stage. Pap smear is a recommended screening method for cancer cervix and its precursors. Pap smear screening in antenatal period presents an opportunity to screen for premalignant cervical lesions and genital infections. This study was undertaken to determine the prevalence of abnormal cervical smears and genital infections among antenatal women.

Methods: It is a prospective study in which, 200 antenatal mothers at booking visit, were included in the study. Details on their demographic characteristics, obstetric profile, and past history of Pap test were collected. Liquid based cytology was used for the test. The cytological results were reported based on the Bethesda classification system 2001.

Results: Among 200 antenatal women 57\% were between 21-25 yrs of age and 18\% were less than 20 years. $38 \%$ of women were less than 20 years of age at the time of beginning of sexual activity. $56 \%$ were primi gravida and others were multi gravida. $95.5 \%$ of women were literate. $89 \%$ of women were unaware of Pap smear test. Among the 200 Pap smear reports, 23\% were normal, 55.5\% nonspecific inflammatory changes, $8.5 \%$ Candida infection and $13 \%$ bacterial vaginosis. None were reported with premalignant changes.

Conclusions: In a population where people do not undergo Pap test due to varied reasons, antenatal Pap test not only provides an excellent opportunity to screen and create awareness for further screening, also helps detect genital infections.
\end{abstract}

Keywords: Antenatal Pap smear, Cervical cancer, Cervical cancer screening, Genital infections, Precancerous lesion, Pregnancy

\section{INTRODUCTION}

Cervical and breast cancers are the leading malignancies in females in India. Cancer cervix is the second most common cancer in the age group 15-45 years. The incidence in India is 20.2 per $1,000,000$ populations. Annually 1, 22,844 cases of cancer cervix are reported, and 67,477 women die of cancer cervix. ${ }^{1}$ In the last few decades there is a decreasing trend in the incidence of cancer cervix and its mortality in many developed countries due to regular cervical cancer screening program. In developing countries, in addition to the prevalence of risk factors like low socio-economy, high parity, early marriage, lack of awareness about cancer cervix and screening programs also contribute to the high incidence and mortality due to cancer cervix. ${ }^{2,3}$

One third of all cancer cervices occur in the reproductive age group. Invasive cancer cervix is considered to be a preventable disease because it has a long pre-invasive state. ${ }^{4}$ Cases can be detected in this pre-invasive stage by proper screening methods done at regular intervals and 
treating it can prevent its progression to invasive cancer. $^{2,5,6}$

According to ACOG recommendation, cervical cancer screening should be done every 3 years from the age of 21 years to 65 years. ${ }^{5}$ In developing countries, where women do not visit clinics for cancer screening, pregnancy is the period when women of reproductive age meet a clinician for the first time and this prenatal visit offers an excellent opportunity to implement cervical screening for cancer cervix and its pre-cursers. ${ }^{5-7}$

Though incidence of invasive cancer cervix is low, 1 in 1000 to 5000 pregnancies, precursors for cervical cancer may be frequently encountered. ${ }^{4}$ The prevalence of abnormal cervical cytology in pregnancy is dependent on the screened population and could vary between $5-8 \%$ of pregnancies. ${ }^{8-10}$ Most of these cervical abnormalities are asymptomatic. $^{2}$ The goal of antenatal screening is to identify these pre-invasive lesions and intervene before progressing to invasive cancer. ${ }^{2}$ This also provides an opportunity to educate and create awareness about cancer cervix and motivate them for future regular Pap smear screening for themselves and members of her community. ${ }^{11}$

In addition, Pap smear also gives information about genital infections such as bacteria, fungus, virus etc. This provides an opportunity to detect asymptomatic genital infections and there by treat it, which otherwise could have an adverse effect on ongoing pregnancy outcomes..$^{11,12}$

Cervical screening during pregnancy is a special circumstance where additional concern is about the wellbeing of the fetus. Pap smear during ante-natal period poses no risk to the fetus and is not associated with an increased rate of miscarriage or preterm labor. Although cytological specimens are more difficult to interpret in pregnancy because of hormonal changes, a Pap test seems to have equivalent accuracy in both pregnant and non-pregnant women with expertise. ${ }^{6}$

While in most developed countries cytological screening is a standard part of antenatal examination, no such screening exists in our country due to lack of awareness, fear and misconception regarding Pap smear. ${ }^{6}$ Hence the need for this study which includes performance of Papsmear screening in antenatal women and analysis of the results and determining the prevalence of abnormal Pap smears and genital infections among women who attend the antenatal clinic of Saveetha Medical College and Hospital.

\section{METHODS}

This is a prospective study, with convenient sampling, conducted in the antenatal clinic at Saveetha Medical College and Hospital. The participants were antenatal women at their first antenatal visit between March 2017 and February 2018. Antenatal women attending antenatal clinic at Saveetha Medical College and Hospital, who had not undergone Pap smear in the previous three years and less than 20 weeks of gestation were included in the study. Women who were not pregnant, women with history of bleeding per vaginum, pregnancies more than 20 weeks of gestational age and women not willing for the test were excluded from the study.

Data was collected using a questionnaire which included participant's demographic characteristics, obstetric profile, and past history of screening cervical cytology. The Pap test was performed after providing information about Pap smear and obtaining consent. Liquid based cytology was used for performing the test. Sample was taken from the squamo-columnar junction using cytobrush and material immediately transferred to the liquid and the container was sent to the Department of Pathology. The cytological results were reported based on the Bethesda classification system 2001.

Patients who had abnormal results were informed, followed up and offered treatment accordingly. Data were analyzed using Microsoft excel and include descriptive statistics for demographic data and expressed in percentage.

\section{RESULTS}

200 antenatal women were included in the study and Pap smears were taken. The results were as follows.

Table 1 represents the age distribution of the study women. Majority of women under study were between 21-25 years of age (57\%). 18 percent of women were less than 20 years.7\% were between 31-35 yrs. Only two women were above 35 years of age. The median age of the women was 24 yrs. So, the majority of study population was comparatively young.

Table 1: Age distribution.

\begin{tabular}{|lll|}
\hline Age in years & Number of women & Percentage \\
\hline 20 and below & 36 & 18 \\
\hline $21-25$ & 115 & 57.5 \\
\hline $26-30$ & 40 & 20 \\
\hline $31-35$ & 7 & 3.5 \\
\hline $36-40$ & 2 & 1 \\
\hline
\end{tabular}

About $38 \%$ of women in the study group were less than 20 years of age at the time of beginning of sexual activity who form the high-risk group. Others (62\%) were 20 years and above (Table 2).

Table 2: Distribution of age at first sexual activity.

\begin{tabular}{|lll|}
\hline $\begin{array}{l}\text { Age at first sexual } \\
\text { activity }\end{array}$ & $\begin{array}{l}\text { Number of } \\
\text { women }\end{array}$ & Percentage \\
\hline$<20$ & 76 & 38 \\
\hline 20 and above & 124 & 62 \\
\hline
\end{tabular}


Primi gravida formed major part of the study group $(56 \%)$, whereas others were gravida two and above (Table 3).

Table 3: Distribution of gravidity.

\begin{tabular}{|lll|}
\hline Gravidity & Number of women & Percentage \\
\hline Primi & 112 & 56 \\
\hline Multi & 88 & 44 \\
\hline
\end{tabular}

The educational status of the women is shown in Table 4. Among 200 women in study group, $95.5 \%$ of women were literate.74\% of women had completed their higher secondary education and $19 \%$ had completed degree. Small proportion of women was illiterate $(7 \%)$.

Table 4: Distribution of education status.

\begin{tabular}{|ll|l|}
\hline Education & Number of women & Percentage \\
\hline Illiterate & 7 & 3.5 \\
\hline Primary & 5 & 2.5 \\
\hline Higher secondary & 148 & 74 \\
\hline Degree & 38 & 19 \\
\hline
\end{tabular}

Assessing the knowledge about Pap smear test, among 200 women, majority of women $(89 \%)$ have not heard about Pap smear test. Only $11 \%$ of women had heard about Pap test (Table 5).

Table 5: Awareness on Pap smear.

\begin{tabular}{|lll} 
A wareness on Pap smear & $\begin{array}{l}\text { Number } \\
\text { of women }\end{array}$ & Percentage \\
\hline Yes & 22 & 11 \\
\hline No & 178 & 89 \\
\hline
\end{tabular}

The Pap smear reports of 200 women are shown in Table 6. Among the 200 Pap smear reports, $23 \%$ of smears were reported to be normal. $55.5 \%$ of the reports showed nonspecific inflammatory changes. Candida infection was seen in $8.5 \%$ and bacterial vaginosis was reported in $13 \%$ of women. None were reported with premalignant changes.

Table 6: Report of Pap smear.

\begin{tabular}{|lll|}
\hline Pap smear report & $\begin{array}{l}\text { Number of } \\
\text { women }\end{array}$ & Percentage \\
\hline Normal & 46 & 23 \\
\hline Nonspecific inflammatory & 111 & 55.5 \\
\hline Candida & 17 & 8.5 \\
\hline Bacterial vaginosis & 26 & 13 \\
\hline
\end{tabular}

\section{DISCUSSION}

Cancer cervix is a preventable and easily detectable cancer. Pap smear is the available gold standard screening test to detect pre-invasive cervical lesions which are amenable to treatment. Though majority of cancer cervix occur in peri-menopausal age group, premalignant changes begin much earlier in twenties. Hence this test is recommended to begin from the age 21 years in all sexually active women and to be done at regular intervals. Pregnant women also fall in this age group. Pap smear can be done safely during pregnancy, which not only helps in detecting pre-invasive lesions but also asymptomatic genital infections that could cause negative impact on pregnancy outcome if untreated. ${ }^{13}$

Women in this study were between 16-37years of age. Majority belonged to 21-25 years of age. This is similar to the study conducted by Radha Bai Prabhu et al in India and Norwegian studies. ${ }^{14,15} 38 \%$ of women were less than 20years of age at the time of beginning of sexual activity, the proportion of which is higher when compared to the study done by Manikkam B. ${ }^{16}$ Majority were 20 years and above when they had begun the sexual activity which is similar to other studies in India. ${ }^{16}$ But studies from Thailand showed a higher proportion of women less than 20 years at the onset of sexual activity which could be one of the reasons for higher incidence of cancer cervix at Thailand. ${ }^{17}$

Proportion of primi gravida were higher $(56 \%)$ in the study, which is similar to results of other studies. ${ }^{16}$ Majority of the women were literate, who had their education more than primary school and only $7 \%$ were illiterate. Only $11 \%$ of the women had heard about Pap test for cervical cancer detection. This is in contrast to study results conducted at Coimbatore by Manikkam, where $80 \%$ of women and Turkish studies showed that $60.7 \%$ women were aware of Pap smear. ${ }^{3,11}$ This difference may be due to difference in population characteristics under study.

Among the Pap smears reported, no pre-malignant lesions were reported. This may be because the majority of the screened women were young. Other studies showed a higher rate of abnormal smears, which may be due to the presence of high risk factors in this population. ${ }^{17}$ In present study majority were reported as nonspecific inflammatory smears $(55.5 \%)$. Candida infection and bacterial vaginosis was reported in $8.5 \%$ and $13 \%$ respectively. Studies from Thailand show higher prevalence of lower genital tract infections. ${ }^{17}$

\section{CONCLUSION}

Cancer cervix being one of the leading cancers is a preventable and treatable cancer if detected at an early stage. The precancerous cervical lesions which begin in reproductive age group are asymptomatic and can be detected by regular cervical screening. In a country where women do not undergo regular cervical screening, antenatal period when the women visit a hospital, offers an excellent opportunity not only to screen for cervical lesions, but educate and create awareness about cancer cervix and motivate them for future regular Pap smear screening for themselves and members of her community. 
Though the incidence of diagnosis of abnormal smears depends on the characteristics of the study population, it gives an opportunity to diagnose genital infections which might affect the pregnancy outcome.

Funding: No funding sources Conflict of interest: None declared

Ethical approval: The study was approved by the Institutional Ethics Committee

\section{REFERENCES}

1. Sreedevi A, Javed R, Dinesh A. Epidemiology of cervical cancer with special focus on India. Int $\mathbf{J}$ Womens Health. 2015;7:405-14.

2. Monteiro PB, Monteiro Filho MP, de Figueirêdo JT, de Lima Saintrain MV, Bruno ZV, Carvalho FH. Cytology-Based Screening during Antenatal Care as a Method for Preventing Cervical Cancer. Asian Pacific J Cancer Prevent. 2017;18(9):2513-8.

3. Ayten Dinc. Pap Smear Screening Results for Turkish Pregnant Women. Asian Pacific J Cancer Prevent. 2012;13(11):5835-8.

4. Gonçalves CV, Duarte G, Costa JSD, Marcolin AC, Bianchi MS, Dias D, Lima LCV. Diagnosis and treatment of cervical cancer during pregnancy. Sao Paulo Med J. 2009;127(6):359-65.

5. Ngaojaruwong N, Vuthiwong C, Punpuckdeekoon P, Thongsorn N. Prevalence of Abnormal Papanicolaou Smear in Pregnant Women at Phramongkutklao Hospital. Thai J Obstet Gynaecol.2008;16(3):179-85.

6. Ingprasarn A, Onaium N. Prevalence of Abnormal Conventional Pap Smear in Pregnant Women, Chonburi Hospital. Thai J Obstet Gynaecol. 2014;22(3):137-42.

7. McIntyre-Seltman K., Lesnock JL. Cervical Cancer Screening in Pregnancy. Obstet Gynecol Clin N Am.2008;35(4):645-58.

8. Economos KA, Perez NV, Delke IS, Collado ML, Tancer ML. Abnormal cervical cytology in pregnancy: a 17- year experience. Obstet Gynecol 1993;81(6):915-8.
9. McDonald SD, Faught W, Gruslin A. Cervical cancer during pregnancy. J Obstet Gynaecol Canada. 2002;24(6):491-8.

10. Shaheen R, Paliwal S, Bakoliya A. Prevalence of abnormal Pap smear in pregnant women attending the antenatal clinic in Dr S N Medical college and attached hospitals, Jodhpur. Indian J App Res. 2017;7(3):69-71.

11. Manikkam B. Screening for cervical cancer during pregnancy. Int $\mathbf{J}$ Community Med Public Health. 2016;3(9):2493-8.

12. Michael CW. The Papanicolaou Smear and the Obstetric Patient: A Simple Test with Great Benefits. Diagnostic Cytopathol.1999;21(1):1-3.

13. Mishra V, Dorairajan G, Neelaiah S, Chinnakali P. Prevalence of abnormal Pap smear during pregnancy in a teaching hospital in South India. Int $\mathbf{J}$ Reprod Contracept Obstet Gynecol. 2015;4(5):1296-9.

14. Velayudham D, Nethaji S.. Opportunistic cervical cancer screening in pregnancy. Int J Med Res Health Sci, 2016;5(1):278-81

15. Nygård $M$, Daltveit $A K$, Thoresen $S \varnothing$, Nygård JF. Effect of an antepartum Pap smear on the coverage of a cervical cancer screening programme: a population-based prospective study. BMC Health Ser Res. 2007;7(1): 10 .

16. Himabindu P, Kanwal A, Vasudha. Pap Smear in Antenatal Women - Routine Screening In Low Resource Settings. IOSR J Dent Med Sci. 2015;14(4):04-5.

17. Khaengkhor $\mathrm{P}$, Mairaing $\mathrm{K}$, Suwannarurk $\mathrm{K}$, Thaweekul Y, Poomtavorn Y, Pattaraarchachai J, Bhamarapravatana K. Prevalence of abnormal cervical cytology by liquid-based cytology in the antenatal care clinic, Thammasat University Hospital. J Medical Assoc Thailand. 201 9;94(2):152.

Cite this article as: Ethirajan S, Srinidhi R, Jayashree K. Pap smear in antepartum women: an opportunity to screen and create awareness. Int J Reprod Contracept Obstet Gynecol 2018;7:4093-6. 